\title{
NUTRITIONAL STATUS AND PHYSICAL DEVELOPMENT OF HIGH-PERFORMANCE COMBAT ATHLETES IN LITHUANIA
}

\author{
Marius Baranauskas ${ }^{1,3}$, Linas Tubelis ${ }^{2,3}$, Rimantas Stukas $^{1}$, Edmundas Švedas ${ }^{4}$, \\ Laimutè Samsoniené ${ }^{1}$, Diana Karanauskien $\dot{e}^{5}$ \\ Vilnius University Faculty of Medicine Public Health Institutel, Vilnius, Lithuania \\ Lithuanian University of Educational Sciences ${ }^{2}$, Vilnius, Lithuania \\ Lithuanian Olympic Sports Centre, Vilnius, Lithuania \\ Lithuanian Sports Medicine Centre ${ }^{4}$, Vilnius, Lithuania \\ Lithuanian Sports University, Kaunas, Lithuania
}

\begin{abstract}
Background. Adequate nutrition is inseparable from athletes' optimal physical development and achieved sports performance. Preparing for the Olympic Games athletes' nutrition must meet certain requirements. Only under appropriate nutrition conditions athletes are enabled to maximize their adaptation to physical loads. Hypothesis: nutrition of Lithuanian high performance athletes in combat sports is adequate. Research aim was to assess nutrition profile and physical development of Lithuanian high performance athletes in combat sports.

Methods. During the competition preparation period of 2012, the actual diets of Lithuanian elite boxers $(n=14)$, and the Greco-Roman wrestlers $(n=29)$ were tested and evaluated. Body composition parameters and physical development of combat athletes were assessed using BIA tetra - polar electrode method. Athletes' actual diets were established using the actual dietary survey method.

Results. Muscle and fat mass indexes of boxers and Greco-Roman wrestlers, $7.5 \pm 3.8$ and $5.4 \pm 2.0$ respectively, show that effective complex preparation measures ensure optimal body condition status of athletes. Nevertheless, the diets of combat sport athletes do not meet the requirements: irrational use of proteins, not enough carbohydrates and polyunsaturated fatty acids, including omega- 6 and omega- 3 fatty acids, vitamins $D_{1}, B_{1}$, PP, minerals, manganese, zinc, calcium and copper, too much intake of fat, saturated fatty acids and cholesterol.

Conclusion. The existing diets of Lithuanian elite combat sports athletes cannot ensure their maximal adaptation to physical loads and must be optimized, individualized and adjusted, adding dietary supplements with extra carbohydrates, essential fatty acids, vitamins, minerals, and in exceptional cases, nutritional supplements with essential amino acids.
\end{abstract} profile.

Keywords: high sports performance, combat sports, boxing, Greco-Roman wrestling, athlete nutrition, nutrition

\section{INTRODUCTION}

$\mathrm{A}$ thletes and specialists training them should pay special attention to diets because proper nutrition is an integral part of optimal physical development of athletes and their achieved optimal performance (American College of Sports Medicine, 2009). Aiming at developing targeted measures to improve planning and management of training high performance athletes, it is clearly important to highlight the nutrition characteristics of different groups of athletes. Preparing for the Olympic Games, athletes' nutrition must meet certain requirements. Only under the conditions of adequate nutrition athletes can ensure their increased energy consumption and 
the body's nutrient needs and thus allow maximum adaptation to physical loads.

There is a lack of research about the nutrition profile of Lithuanian combat athletes. So far, it has not been established whether nutrition of elite combat athletes meets the requirements, no recommendations have been provided for the optimization of combat athletes' diets. Therefore, in order to more effectively manage the training of Lithuanian combat athletes for excellence, their actual nutritional studies are among the most important and relevant. Only after the assessment of their nutrition profile it is possible to rationally combine it with organized training process so as to reach the best possible sports results and at the same time protect and preserve athletes' health. This determined our research aim - to assess actual nutrition profile and body composition of Lithuanian high performance boxers and GrecoRoman wrestlers.

\section{METHODS}

During the competition preparation period of 2012, the actual diets and physical development of Lithuanian elite combat athletes $(n=43)$ were evaluated. Research sample involved combat athletes who trained $155 \pm 40 \mathrm{~min}$ a day (years of training $7.2 \pm 3.8$ ). All in all, $95 \%$ of elite combat athletes included in the lists of those training for the Olympic Games were tested: 14 boxers and 24 Greco-Roman wrestlers. The mean age of research participants was $20.5 \pm 3.8$ years $(18.4 \pm 0.8$ years for boxers and $21.5 \pm 4.3$ years for Greco-Roman wrestlers).

Athletes' body composition analysis was performed. Athletes' height was measured using electronic scales at the Lithuanian Sports Medicine Centre. Body weight and body weight of the individual components: lean body weight $(\mathrm{kg}$ and \%), muscle mass ( $\mathrm{kg}$ and \%), fat mass ( $\mathrm{kg}$ and \%) measurements were performed in the Lithuanian Olympic Sports Centre applying body composition analyser X-SCAN and using BIA tetrapolar electrode method which had been used in the studies with other athletes used and recommended by other researchers (American College of Sports Medicine, 2009; Moon, 2013). In addition, athletes' body mass index (BMI) as well as muscle and fat mass index (MFMI) were calculated and assessed (Skernevičius, Raslanas \& Dadelienè, 2004).

Athletes' actual diets were established using the actual dietary survey method. Respondents were surveyed by a trained interviewer applying in-depth interviews at the Lithuanian Olympic Sports Centre. Following the actual dietary survey method, consumed foods and dishes were recorded for each athlete. The actual nutrition survey was performed using special Atlas with pictures of foods and dishes, which contains different portions of foods and meals evaluated in grams in order to capture all food and dishes eaten as well as their and quantities (Maisto produktu ir patiekalu porciju nuotrauku atlasas, 2007). Athletes' average daily food rations were measured, and their chemical composition and energy value were determined using the chemical composition tables (Sučiliene \& Abaravičius, 2002). Nutrient intake was assessed taking into account the recommendations provided in the scientific literature (American College of Sports Medicine, 2009; Burke, 2010; Kreider et al., 2010). Assurance of the energy body needs was set by method of indirect alimony calorimetry (American College of Sports Medicine, 2009; Ainsworth et al., 2011). Intake of biologically active substances in the quantities of the recommended daily intake (RDI) was assessed by approved vitamins and minerals RDI in Lithuania (Rekomenduojamos paros maistiniu medžiagu ir energijos normos, 1999).

In accordance with the recommendations, the adequacy of intake of nutrients to the recommended quantities was estimated and expressed as a percentage of the recommended amount (intake/ recommended amount $\mathrm{x}$ 100). As the RDI of vitamins and minerals depends on age and gender, the intake of these substances was expressed as a percentage (\%) of the RDI (intake/RDI x 100). Referring to the intake levels of macronutrients and micronutrients, athletes were divided into appropriate groups: athletes consuming less than the recommended amount (or) RDI, consuming the recommended amount (or) RDI, and consuming more than the recommended amount (or) RDI.

Statistical data analysis was performed using the statistical programme SPSS (Statistical Package for Social Sciences) v. 15.0. Hypothesis about the data normality was tested as follows: a visual comparison of actual histograms with normal distribution was performed additionally applying Kolmogorov-Smirnov two-sample test and Shapiro-Wilk tests. Data analysis applied conventional descriptive statistics methods to calculate the arithmetic means and standard deviations $(S D)$. Student's $(t)$ test was used for the comparison of the mean values for two independent groups of respondents. Categorical data analysis 
was performed using Fisher's exact test. The level of significance to verify the hypothesis was $\alpha=.05$. The difference of results was considered statistically significant when the $p$ value obtained was less than or equal to .05 .

\section{RESULTS}

The assessment of body composition of combat athletes showed that boxers' and wrestlers' body weight ranged within the normal values (Table 1). This is confirmed by the BMI of the Lithuanian Olympic boxers and wrestlers, which was $20.7 \pm$ $3.2 \mathrm{~kg} / \mathrm{m}^{2}$ and $23.5 \pm 3.2 \mathrm{~kg} / \mathrm{m}^{2}$ respectively. The duration, intensity, volume, developed physical abilities and characteristics of energy expenditure of the investigated athletes during their sports activities were similar. In case of long-term sports experience (in our research $-7.2 \pm 3.8$ years), in the preparation period for the Olympic Games, physical development of boxers and wrestlers should not particularly differ and must meet the nutrition profile requirements for high-performance athletes. Advanced athletes' body composition analysis showed that the lean body weight (\%), fat mass (\%) and muscle mass (\%) of boxers and wrestlers were not different. Meanwhile boxers' BMI was significantly higher than the wrestlers' BMI ( $p=$ .001). Nevertheless, combat athletes according to MFMI were identical (boxers' MFMI was $7.5 \pm$ 3.8, and the Greco-Roman wrestlers' MFMI $-5.4 \pm$ $2.0, p=.070)$. MFMI indicators of athletes in both sports are rated as high, indicating a particularly good physical development status of Lithuanian elite combat athletes.

The analysis of the actual diets of athletes showed that the energy intake (EI) of combat athletes $(3292.9 \pm 800.6 \mathrm{kcal}$ or $48.6 \pm 15.1 \mathrm{kcal} /$ $\mathrm{kg})$ was slightly less than the daily estimated energy requirement (EER) $(3628.2 \pm 763.8 \mathrm{kcal}$ or $51.6 \pm 5.9 \mathrm{kcal} / \mathrm{kg}$ ) (Table 2). This is confirmed by the percentage ratio of EI and EER. The overall negative ratio (EIx100/EER) - $94.4 \pm 29.3 \%$ - is largely determined by the lower energy values of Greco-Roman wrestlers' rations. Meanwhile boxers' energy intake with food $101.3 \pm 37.4 \%$ corresponds to the body's daily energy expenditure.

In our study, quantities of boxers' and wrestlers' consumed carbohydrates, proteins and fat do not different. Boxers' and Greco-Roman wrestlers' average consumption of carbohydrates are respectively $6.3 \pm 2.1 \mathrm{~g} / \mathrm{kg}$ and $5.6 \pm 2.0 \mathrm{~g} / \mathrm{kg}$.
Table 1. Anthropometric data of combat sports athletes in Lithuania

Note. BW - body weight

Table 2. Energy intake of combat sports athletes in Lithuania

Note. BW - body weight.

\begin{tabular}{|l|c|c|c|c|c|}
\hline \multirow{2}{*}{ Anthropometrics } & \multicolumn{1}{|c|}{$\begin{array}{c}\text { Boxers } \\
(\boldsymbol{n}=\mathbf{1 4})\end{array}$} & $\begin{array}{c}\text { Greco-Roman } \\
\text { wrestlers } \\
(\boldsymbol{n}=\mathbf{2 9})\end{array}$ & $\begin{array}{c}\text { Recom- } \\
\text { mended }\end{array}$ & $\boldsymbol{p}$ value & $\boldsymbol{t}$-test \\
\cline { 2 - 6 } & \multicolumn{5}{|c|}{ Mean $\pm \boldsymbol{S D}$} \\
\hline Height (cm) & $171.2 \pm 7.6$ & $176.8 \pm 8.4$ & & .044 & -2.080 \\
\hline Body weight (BW) (kg) & $62.1 \pm 14.4$ & $74.9 \pm 14.9$ & & .011 & -2.666 \\
\hline Total body fluid, kg) & $38.3 \pm 5.9$ & $45.1 \pm 8.0$ & & .007 & -2.841 \\
\hline Total body fluid (\% of BW) & $62.4 \pm 4.5$ & $60.5 \pm 3.0$ & $55-65$ & .114 & 1.613 \\
\hline Lean body mass (kg) & $53.0 \pm 7.9$ & $62.7 \pm 11.1$ & & .006 & -2.904 \\
\hline Lean body mass (\% of BW) & $86.6 \pm 6.4$ & $84.1 \pm 4.2$ & $80-85$ & .136 & 1.520 \\
\hline Muscle mass (kg) & $49.4 \pm 7.1$ & $58.3 \pm 10.3$ & & .006 & -2.907 \\
\hline Muscle mass (\% of BW) & $80.7 \pm 6.3$ & $78.3 \pm 4.1$ & $74-80$ & .133 & 1.534 \\
\hline Fat mass (kg) & $9.1 \pm 7.0$ & $12.3 \pm 5.0$ & & .095 & -1.709 \\
\hline Fat mass (\% of BW) & $13.4 \pm 6.4$ & $15.8 \pm 4.1$ & $10-14$ & .155 & -1.447 \\
\hline Body mass index (BMI) (kg/m ${ }^{2)}$ & $20.7 \pm 3.2$ & $23.5 \pm 3.2$ & $18.5-24.9$ & .010 & -2.712 \\
\hline $\begin{array}{l}\text { Muscle and fat mass index } \\
\text { (MFMI) }\end{array}$ & $7.5 \pm 3.8$ & $5.4 \pm 2.0$ & $4.7-6.0$ & .070 & 1.938 \\
\hline
\end{tabular}

\begin{tabular}{|l|c|c|c|}
\hline \multicolumn{1}{|c|}{$\begin{array}{c}\text { Estimated energy requirement } \\
\text { and energy intake }\end{array}$} & Boxers & $\begin{array}{c}\text { Greco-Roman } \\
\text { wrestlers }\end{array}$ & Total \\
\cline { 2 - 4 } & & \multicolumn{3}{c|}{ Mean \pm SD } \\
\hline Estimated Energy Requirement (EER) (kcal) & $3176.8 \pm 722.4$ & $3846.2 \pm 694.0$ & $3628.2 \pm 763.8$ \\
\hline $\begin{array}{l}\text { Estimated Energy Requirement (EER) (kcal/ } \\
\mathrm{kg} / \mathrm{BW})\end{array}$ & $51.6 \pm 8.4$ & $51.6 \pm 4.4$ & $51.6 \pm 5.9$ \\
\hline Energy intake (EI) (kcal) & $3034.6 \pm 711.0$ & $3417.6 \pm 823.0$ & $3292.9 \pm 800.6$ \\
\hline Energy intake (EI) (kcal/kg/BW) & $51.4 \pm 17.1$ & $47.2 \pm 14.2$ & $48.6 \pm 15.1$ \\
\hline$\%$ EEI & $101.3 \pm 37.4$ & $91.0 \pm 24.5$ & $94.4 \pm 29.3$ \\
\hline
\end{tabular}


Regardless of the branch of sport, combat athletes consume the same amount of proteins $(1.7 \pm 0.6 \mathrm{~g} /$ $\mathrm{kg}$ ) and similar amounts of essential amino acids, fat, saturated and polyunsaturated fatty acids (Table 3).

A more detailed analysis of the research results confirmed that the recommended amount of carbohydrates is not consumed by $74.4 \%$ of athletes, polyunsaturated fatty acids $-55.8 \%$, omega- 6 fatty acids $-32.6 \%$, omega- 3 fatty acids $100.0 \%$ combat athletes (Table 4). Meanwhile,
$60.5 \%$ combat athletes consume too much fat, $100.0 \%$ - too much saturated fatty acid, and $81.4 \%$ - too much cholesterol. It should be noted that proteins are consumed irrationally by combat athletes. Dietary intake of $46.5 \%$ athletes is too low and $41.9 \%$ - too high in protein content. Only $11.6 \%$ of the Lithuanian elite combat athletes consume proteins and essential amino acids according to the recommendations. More often athletes' diets lack essential amino acids leucine and phenylalanine. In

\begin{tabular}{|l|c|c|c|}
\hline \multirow{2}{*}{ Macronutrients } & Boxers & $\begin{array}{c}\text { Greco-Roman } \\
\text { wrestlers }\end{array}$ & \multirow{2}{*}{ RDI } \\
\cline { 2 - 3 } & \multicolumn{2}{|c|}{ Mean \pm SD } & \\
\hline Carbohydrate $(\mathrm{g} / \mathrm{kg} / \mathrm{BW})$ & $6.3 \pm 2.1$ & $5.6 \pm 2.0$ & $7.0-10.0$ \\
\hline Protein, $\mathrm{g} / \mathrm{kg} / \mathrm{BW}$ & $1.7 \pm 0.6$ & $1.7 \pm 0.6$ & $1.6-1.8$ \\
\hline $\begin{array}{l}\text { Non-essential amino } \\
\text { acids }(\mathrm{mg} / \mathrm{kg} / \mathrm{BW})\end{array}$ & $643.6 \pm 227.7$ & $614.8 \pm 214.4$ & $436-491$ \\
\hline Valine $(\mathrm{mg} / \mathrm{kg} / \mathrm{BW})$ & $96.3 \pm 34.9$ & $92.5 \pm 31.8$ & $63-71$ \\
\hline Leucine $(\mathrm{mg} / \mathrm{kg} / \mathrm{BW})$ & $136.9 \pm 48.5$ & $131.8 \pm 48.3$ & $95-106$ \\
\hline Isoleucine $(\mathrm{mg} / \mathrm{kg} / \mathrm{BW})$ & $80.5 \pm 29.2$ & $77.2 \pm 26.8$ & $48-55$ \\
\hline Lysine $(\mathrm{mg} / \mathrm{kg} / \mathrm{BW})$ & $119.6 \pm 40.8$ & $112.5 \pm 38.7$ & $73-82$ \\
\hline Methionine $(\mathrm{mg} / \mathrm{kg} / \mathrm{BW})$ & $38.2 \pm 13.3$ & $37.5 \pm 14.0$ & $24-27$ \\
\hline Threonine $(\mathrm{mg} / \mathrm{kg} / \mathrm{BW})$ & $68.7 \pm 24.7$ & $65.6 \pm 22.0$ & $36-41$ \\
\hline Tryptophan $(\mathrm{mg} / \mathrm{kg} / \mathrm{BW})$ & $23.6 \pm 9.1$ & $21.5 \pm 7.2$ & $10-11$ \\
\hline Phenylalanine $(\mathrm{mg} / \mathrm{kg} / \mathrm{BW})$ & $79.7 \pm 29.0$ & $76.2 \pm 26.9$ & $61-68$ \\
\hline Histidine $(\mathrm{mg} / \mathrm{kg} / \mathrm{BW})$ & $51.2 \pm 18.4$ & $49.7 \pm 17.9$ & $24-27$ \\
\hline Fat $(\%)$ & $36.6 \pm 5.8$ & $38.8 \pm 6.3$ & $20-35$ \\
\hline Saturated fatty acids (\%) & $14.5 \pm 2.5$ & $14.2 \pm 2.4$ & $\leq 10$ \\
\hline Polyunsaturated fatty acids $(\%)$ & $5.3 \pm 1.3$ & $6.4 \pm 1.7$ & $6-10$ \\
\hline Omega-6 fatty acids (\%) & $4.8 \pm 1.3$ & $5.9 \pm 1.6$ & $5-8$ \\
\hline Omega-3 fatty acids (\%) & $0.3 \pm 0.1$ & $0.4 \pm 0.1$ & $1-2$ \\
\hline Cholesterol (mg) & $754.3 \pm 446.4$ & $789.7 \pm 361.4$ & $\leq 500$ \\
\hline
\end{tabular}

Table 3. Macronutrient intake of combat sports athletes in Lithuania

Note. BW - body weight, RDI recommended daily intake.

\begin{tabular}{|c|c|c|c|}
\hline \multirow{3}{*}{ Macronutrients } & \multicolumn{3}{|c|}{ Intake of macronutrients } \\
\hline & Is less than RDI & Meets the RDI & Exceeds the RDI \\
\hline & $(\%)$ & $(\%)$ & $(\%)$ \\
\hline Carbohydrate $(\mathrm{g} / \mathrm{kg} / \mathrm{BW})$ & 74.4 & 20.9 & 4.7 \\
\hline Protein, g/kg/ BW & 46.5 & 11.6 & 41.9 \\
\hline Non-essential amino acids (mg/kg/BW) & 20.9 & 11.6 & 67.4 \\
\hline Valine (mg/kg/BW) & 16.3 & 11.6 & 72.1 \\
\hline Leucine $(\mathrm{mg} / \mathrm{kg} / \mathrm{BW})$ & 25.6 & 7.0 & 67.4 \\
\hline Isoleucine (mg/kg/BW) & 11.6 & 9.3 & 79.1 \\
\hline Lysine (mg/kg/BW) & 14.0 & 7.0 & 79.1 \\
\hline Methionine (mg/kg/BW) & 16.3 & 9.3 & 74.4 \\
\hline Threonine (mg/kg/BW) & 7.0 & 4.7 & 88.4 \\
\hline Tryptophan (mg/kg/BW) & 4.7 & 2.3 & 93.0 \\
\hline Phenylalanine (mg/kg/BW) & 32.6 & 9.3 & 58.1 \\
\hline Histidine $(\mathrm{mg} / \mathrm{kg} / \mathrm{BW})$ & 7.0 & 2.3 & 90.7 \\
\hline Fat $(\%)$ & - & 39.5 & 60.5 \\
\hline Saturated fatty acids $(\%)$ & - & - & 100.0 \\
\hline Polyunsaturated fatty acids (\%) & 55.8 & 39.5 & $4.7(2)$ \\
\hline Omega-6 fatty acids (\%) & 32.6 & 60.5 & $7.0(3)$ \\
\hline Omega-3 fatty acids (\%) & 100.0 & - & - \\
\hline Cholesterol (mg) & - & 18.6 & $81.4(35)$ \\
\hline
\end{tabular}

Table 4. The distribution of athletes' (in per cent) intake of macronutrients 
order to assess the actual dies of combat athletes, we analysed the composition of biologically active elements in their rations (Table 5). The evaluation of boxers' and the Greco-Roman wrestlers' body supply with vitamins and minerals, it appeared that $88.4 \%$ of athletes do not get vitamin D with food. Average intakes of vitamin D for boxers and Greco-Roman wrestlers respectively equal to
$3.3 \pm 1.4 \mathrm{mg}$ and $3.2 \pm 1.6 \mathrm{mg}$, do not reach the recommended amount and represent only 63$66 \%$ RDI. In addition, regardless of the branch of sport, $34.9 \%$ combat athletes consume vitamin B1, $23.3 \%$ - vitamin PP, $30.2 \%$ - calcium, 34.9\% - zinc, $60.5 \%$ - manganese and $23.3 \%$ - copper below the RDI with their dietary intake (Table 6).
Table 5. Micronutrient intake of combat sports athletes in Lithuania

Note. RDI - recommended daily intake.

\begin{tabular}{|l|c|c|c|c|}
\hline \multirow{2}{*}{$\begin{array}{c}\text { Vitamins and } \\
\text { minerals }\end{array}$} & \multicolumn{2}{|c|}{ Boxers } & \multicolumn{2}{c|}{ Greco-Roman wrestlers } \\
\cline { 2 - 5 } & Intake & \% of RDI & Intake & \% of RDI \\
\hline Vitamin A $(\mathrm{mg})$ & $1.1 \pm 0.4$ & $107.0 \pm 36.2$ & $1.2 \pm 0.4$ & $132.7 \pm 56.0$ \\
\hline Vitamin D $(\mu \mathrm{g})$ & $3.3 \pm 1.4$ & $66.0 \pm 28.8$ & $3.2 \pm 1.6$ & $63.6 \pm 31.8$ \\
\hline Vitamin $\mathrm{E}(\mathrm{mg})$ & $17.5 \pm 6.7$ & $178.4 \pm 67.3$ & $22.1 \pm 6.6$ & $226.9 \pm 68.0$ \\
\hline Vitamin $\mathrm{C}^{(\mathrm{mg})}$ & $146.8 \pm 127.7$ & $247.0 \pm 212.0$ & $109.5 \pm 94.4$ & $184.6 \pm 154.9$ \\
\hline Vitamin $\mathrm{B}_{1}(\mathrm{mg})$ & $1.8 \pm 0.6$ & $127.4 \pm 45.1$ & $2.2 \pm 1.0$ & $128.0 \pm 54.9$ \\
\hline Vitamin $\mathrm{B}_{2}(\mathrm{mg})$ & $2.7 \pm 0.9$ & $159.4 \pm 57.0$ & $2.9 \pm 1.0$ & $169.4 \pm 60.0$ \\
\hline Vitamin $\mathrm{B}_{6}(\mathrm{mg})$ & $3.4 \pm 1.0$ & $171.8 \pm 49.5$ & $3.3 \pm 0.9$ & $183.9 \pm 58.0$ \\
\hline Vitamin $\mathrm{B}_{12}(\mathrm{mg})$ & $5.3 \pm 2.6$ & $175.7 \pm 87.5$ & $6.6 \pm 2.9$ & $218.4 \pm 95.6$ \\
\hline Vitamin $\mathrm{B}_{9}(\mathrm{mg})$ & $254.8 \pm 58.9$ & $130.7 \pm 33.3$ & $280.0 \pm 117.7$ & $128.8 \pm 57.6$ \\
\hline Vitamin $\mathrm{PP}(\mathrm{mg})$ & $23.0 \pm 4.4$ & $129.0 \pm 26.5$ & $26.5 \pm 7.1$ & $130.6 \pm 38.2$ \\
\hline Sodium $(\mathrm{mg})$ & $3786.4 \pm 1271.8$ & $252.4 \pm 84.8$ & $4762.2 \pm 1683.3$ & $317.5 \pm 112.2$ \\
\hline Potassium $(\mathrm{mg})$ & $4761.7 \pm 1634.2$ & $190.5 \pm 65.4$ & $4523.4 \pm 1489.1$ & $180.9 \pm 59.6$ \\
\hline Calcium $(\mathrm{mg})$ & $1081.2 \pm 423.9$ & $135.1 \pm 53.0$ & $1269.2 \pm 489.9$ & $148.6 \pm 58.3$ \\
\hline Magnesium $(\mathrm{mg})$ & $422.9 \pm 118.8$ & $106.6 \pm 29.2$ & $510.1 \pm 146.3$ & $142.7 \pm 49.2$ \\
\hline Zinc $(\mathrm{mg})$ & $15.1 \pm 3.5$ & $100.6 \pm 23.3$ & $17.2 \pm 4.8$ & $124.2 \pm 40.5$ \\
\hline Phosphorus $(\mathrm{mg})$ & $1662.9 \pm 414.2$ & $138.6 \pm 34.5$ & $1931.3 \pm 502.8$ & $178.1 \pm 55.4$ \\
\hline Manganese $(\mathrm{mg})$ & $4.2 \pm 1.7$ & $83.5 \pm 33.2$ & $5.0 \pm 1.9$ & $99.7 \pm 37.2$ \\
\hline Iron $(\mathrm{mg})$ & $24.4 \pm 6.3$ & $203.1 \pm 52.8$ & $24.4 \pm 6.0$ & $218.2 \pm 65.5$ \\
\hline Cooper $(\mathrm{mg})$ & $2.3 \pm 0.5$ & $117.1 \pm 23.9$ & $2.5 \pm 0.7$ & $124.5 \pm 34.5$ \\
\hline
\end{tabular}

Table 6. The distribution of athletes' (in per cent) intake of micronutrients (according to the type of combat sports)
Note. group 1 - boxers (\%), group 2 - GrecoRoman wrestlers (\%), RDI - recommended daily intake, * - Fisher's exact test.

\begin{tabular}{|c|c|c|c|c|c|c|c|}
\hline \multirow[b]{2}{*}{$\begin{array}{l}\text { Vitamins and } \\
\text { minerals }\end{array}$} & \multicolumn{2}{|c|}{ Boxers } & \multicolumn{2}{|c|}{$\begin{array}{c}\text { Greco-Roman } \\
\text { wrestlers }\end{array}$} & \multicolumn{2}{|c|}{ Total } & \multirow{2}{*}{$\begin{array}{c}\text { Difference } \\
\text { between } \\
\text { group } 1 \\
\text { and } \\
\text { group 2 } \\
(p \text { value*) }\end{array}$} \\
\hline & $\begin{array}{c}\text { Intake is } \\
\text { less than } \\
\text { RDI }\end{array}$ & $\begin{array}{c}\text { Intake } \\
\text { meets or } \\
\text { exceeds } \\
\text { the RDI }\end{array}$ & $\begin{array}{c}\text { Intake } \\
\text { is less } \\
\text { than } \\
\text { RDI }\end{array}$ & $\begin{array}{l}\text { Intake } \\
\text { meets or } \\
\text { exceeds } \\
\text { the RDI }\end{array}$ & $\begin{array}{c}\text { Intake is } \\
\text { less than } \\
\text { RDI }\end{array}$ & $\begin{array}{c}\text { Intake } \\
\text { meets or } \\
\text { exceeds } \\
\text { the RDI }\end{array}$ & \\
\hline Vitamin A (mg) & 57.1 & 42.9 & 27.6 & 72.4 & 37.2 & 62.8 & .050 \\
\hline Vitamin D $(\mu \mathrm{g})$ & 85.7 & 14.3 & 89.7 & 10.3 & 88.4 & 11.6 & .531 \\
\hline Vitamin E (mg) & 7.1 & 92.9 & 0.0 & 100.0 & 2.3 & 97.7 & .326 \\
\hline Vitamin C (mg) & 7.1 & 92.9 & 34.5 & 65.5 & 25.6 & 65.5 & .049 \\
\hline Vitamin $B_{1}(\mathrm{mg})$ & 42.9 & 57.1 & 31.0 & 69.0 & 34.9 & 65.1 & .507 \\
\hline Vitamin $\mathrm{B}_{2}(\mathrm{mg})$ & 14.3 & 85.7 & 3.4 & 96.6 & 7.0 & 93.0 & .243 \\
\hline Vitamin $B_{6}(\mathrm{mg})$ & 14.3 & 85.7 & 3.4 & 96.6 & 7.0 & 93.0 & .243 \\
\hline Vitamin $\mathrm{B}_{12}(\mathrm{mg})$ & 28.6 & 71.4 & 10.3 & 88.7 & 16.3 & 83.7 & .142 \\
\hline Vitamin $\mathrm{B}_{9}(\mathrm{mg})$ & 14.3 & 85.7 & 34.5 & 65.5 & 27.9 & 72.1 & .050 \\
\hline Vitamin PP (mg) & 14.3 & 85.7 & 27.6 & 72.4 & 23.3 & 76.7 & .287 \\
\hline Sodium (mg) & - & 100.0 & - & 100.0 & - & 100.0 & - \\
\hline Potassium (mg) & 7.1 & 92.9 & 3.4 & 96.6 & 4.7 & 95.3 & .550 \\
\hline Calcium (mg) & 28.6 & 71.4 & 31.0 & 69.0 & 30.2 & 69.8 & .581 \\
\hline Magnesium (mg) & 42.9 & 57.1 & 10.3 & 89.7 & 20.9 & 79.1 & .022 \\
\hline Zinc (mg) & 35.7 & 64.3 & 34.5 & 65.5 & 34.9 & 65.1 & .589 \\
\hline Phosphorus (mg) & 14.3 & 85.7 & 0.0 & 100.0 & 4.7 & 95.3 & .101 \\
\hline Manganese (mg) & 71.4 & 28.6 & 55.2 & 44.8 & 60.5 & 39.5 & .247 \\
\hline Iron (mg) & 0.0 & 100.0 & 0.0 & 100.0 & - & 100.0 & - \\
\hline Cooper (mg) & 14.3 & 85.7 & 27.6 & 72.4 & 23.3 & 76.7 & .287 \\
\hline
\end{tabular}


The assessment of vitamin and mineral intake of different branches of combat sport revealed differences (Table 6). Significantly higher proportion of boxers does not get the recommended dietary vitamin A $(57.1 \%)(p=.050)$ and the mineral magnesium $(42.9 \%)(p=.022)$ were found. Meanwhile, intake of vitamin $\mathrm{C}(p=.049)$ and vitamin $\mathrm{B} 9(p=.050)$ is insufficient in the GrecoRoman wrestlers' $(34.5 \%)$ diets.

\section{DISCUSSION}

Proper nutrition is one of the key determinants of the adaptation to physical loads. One of the most important nutritional requirements for athletes is the optimal supply of carbohydrates for athletes' bodies (Burke, 2010). The findings of our study show that Lithuanian elite combat athletes do not get the recommended carbohydrate content of $7-10 \mathrm{~g} / \mathrm{kg}$ body weight with food. A similar carbohydrate intake $(3.9-4.7 \mathrm{~g} / \mathrm{kg}$ ) not reaching the recommended amount has been established for combat athletes in Greece, France, Spain, England, and Israel (Finaud et al., 2006; Prouteau, Benhamou, \& Courteix, 2006 ; Fleming \& Costarelli, 2007; Simatos, 2007; Sillero Quintana, Garcia Aparicio, Torres Garcia, \& Garrido Pastor, 2010).

Low-carbohydrate diets are often associated with excessive consumption of fat. No exceptions are Lithuanian elite combat athletes traditionally taking too high-fat foods. We found that the combat athletes consumed too much fat and saturated fatty acid. In contrast, in other countries combat athletes consume lower-fat foods and the energy value supplied by fat in their nutrition (26-35\%) does not exceed the recommended dose (20-35\%) (Finaud et al., 2006; Rossi, Goya, Matayoshi, Pereira, \& Bernardo da Silva, 2009; Clarys, Ramon, hagman, Deriemaeker, \& Zinzen, 2010; Martins \& e Rocha, 2010; Sillero Quintana et al., 2010). Besides, in other states combat athletes consume only 307$566 \mathrm{mg}$ of cholesterol and this amount does not exceed the recommended one (Martins \& e Rocha, 2010; Sillero Quintana et al., 2010). Meanwhile, our research participants consumed cholesterol twice as much $(754-790 \mathrm{mg})$ as in other countries, and over 1.5 times the recommended amount $(\leq 500 \mathrm{mg})$.

According to the research data about athlete nutrition, high contents of fat consumption are not associated with the increase of cholesterol and triacylglycerol concentrations in the blood, when the energy intake with food does not exceed the energy expenditure. Consuming increased fat content in the diet, athletes' fat mass, resting heart rate, blood pressure, oxidative stress and lipid peroxidation in the body do not increase and has no negative impact on the immune system of athletes (Venkatraman \& Pendergast, 2001). On the other hand, strenuous exercise promotes amino acid methionine metabolism and increases the level of the homocysteine in the body, which is the stimulating risk factor of cardiovascular disease emergence. Higher homocysteine levels are also caused by higher fat and saturated fat intake (Czajkowska, Lutosławska, Mazurek, Ambroszkiewicz, \& Zmijewskiet, 2011). Thus, it would be reasonable for Lithuanian Olympic combat athletes to reduce fat and saturated fatty acids in their diets and increase the intake of deficient polyunsaturated fatty acids (especially omega-3 fatty acids).

In addition, using too much fat Lithuanian elite combat athletes consume too little carbohydrates. Low-carbohydrate diet slows down the body's adaptation to physical loads (Hawley, Burke, Phillips, \& Spriet, 2011), weakens the immune system, and athletes faster start feeling fatigue during exercise (Burke, 2010). It should be noted that Lithuanian elite combat athletes train 3-4 hours every day and overcome physical loads in the work area of high intensity. Consumption of a small amount of carbohydrates does not fully restore endogenous carbohydrate stores in the body between sports practice sessions and requires more efforts of the central nervous system to deal with physical stress; it is also a risk factor of overtraining (Burke, 2010).

One of the sports nutrition requirements is an adequate intake of proteins and essential amino acids. As shown by the research results, in other countries dietary protein deficiency in combat athletes is rarely determined (Simatos, 2004; Finaud et al., 2006; Fleming \& Costarelli, 2007). On the contrary, in many countries - Spain, Belgium, Brazil, Israel and Iran - the dietary intake of combat athletes meets or exceeds the recommended protein content (Rossi et al., 2009; Clarys et al., 2010; Sillero Quintana et al., 2010; Moran et al., 2012; Daneshvar et al., 2013). Our research results are different. We found that more than $40 \%$ of our surveyed Lithuanian combat athletes consume insufficient of or excessive amounts of protein. It can be noted that protein 
deficiency in Lithuanian combat athletes' nutrition is one of the nutritional disadvantages potentially causing slower adaptation to physical loads. Therefore, supplementation of essential amino acids in food supplements in exceptional cases is reasonable and advisable. On the other hand, higher amounts of proteins than the recommended ones do not slow down the body's adaptation to physical loads. Depending on the duration, intensity, and volume of physical loads, higher protein content in the diet may be recommended for combat athletes. Scientific studies have shown that body's need for protein in elite athletes increases, and the dietary intake of $1.8-2.0 \mathrm{~g} / \mathrm{kg}$ body weight of protein is considered optimal (Burd, Tang, Moore, \& Philips, 2009).

With their food athletes must consume not only the recommended nutrients, but also vitamins and minerals. In our study, Lithuanian combat athletes' diets lack vitamin D, B1, PP, minerals, manganese, zinc, calcium and copper. Similarly, in other countries combat athletes' lack vitamins B1 and $\mathrm{D}$, minerals, calcium and zinc. Insufficient amount of vitamin B1 in the diets of athletes in countries is $1.0-1.4 \mathrm{mg}$ (Filaire, Maso, Degoutte, Jouanel, \& Lac, 2001; Simatos, 2004; Martins, e Rocha, 2010), vitamin D - 2.8-3.0 $\mu$ g (Martins, e Rocha, 2010; Moran et al., 2012), calcium - 600-1000 mg (Simatos, 2004; Fleming \& Costarelli, 2007; Martins \& e Rocha, 2010; Moran et al., 2012), and zinc - 11.9-12.5 mg (Moran et al., 2012; Daneshvar et al., 2013). In addition, our obtained results also revealed inequalities arising from the branch of sport. It turned out that boxers' diets lacked vitamin A and mineral magnesium, and GrecoRoman wrestlers' diets lacked vitamins $\mathrm{C}$ and B9. It should be noted that in other countries, the deficiency of vitamins C, B9 and magnesium has not been determined in combat athletes (Simatos, 2004; Rossi et al., 2009; Martins \& e Rocha, 2010; Moran et al., 2012; Daneshvar et al., 2013), which shows that in other countries athletes optimize the supply of their bodies with vitamins and minerals. There is no doubt that nutrition of our Lithuanian combat athletes must be optimized and additional vitamins and minerals in food supplements must be consumed.

\section{CONCLUSIONS}

1. Under the influence of complex training tools, Lithuanian elite boxers and Greco-Roman wrestlers have developed an optimal physical condition, but the peculiarities of current athletes' diets still cannot induce maximal adaptation to long-term and (or) an intensive, large-scale physical loads. Combat athletes' diets do not fully meet the requirements of proper nutrition due to irrational use of proteins, not enough carbohydrates, polyunsaturated (omega-6 and omega-3) fatty acids, vitamin $\mathrm{D}, \mathrm{B}_{1}, \mathrm{PP}$, minerals, manganese, zinc, calcium and copper, and excessive consumption of fat, saturated fatty acids and cholesterol. Boxers' diets are deficient in vitamin A and magnesium, and the Greco-Roman wrestlers' diets lack vitamin $\mathrm{C}$ and $\mathrm{B}_{9}$.

2. Nutrition of Lithuanian elite combat athletes must be optimized, individualized and adjusted. In order to ensure optimal body needs with nutrients and vitamins as well as minerals, it is recommended to supplement boxers' and Greco-Roman wrestlers' diets with carbohydrates, essential fatty acids, vitamins, minerals, dietary supplements, and in exceptional cases, with essential amino acids, and nutritional supplements.

\section{REFERENCES}

Ainsworth, B. E., Haskell, W. L., Herrmann, S. D., Meckes, N., Bassett, Jr., D. R., Tudor-Locke, C., ... Leon, A. S. (2011). Compendium of physical activities: A second update of codes and MET values. Medicine and Science in Sports and Exercise, 43(1), 1575-1581. doi:10.1249/MSS.0b013e31821ece12 American College of Sports Medicine, American dietetic Association, and Dietitians of Canada. Nutrition and Athletic Performance. Joint Position Statement. (2009). Medicine and Science in Sports and Exercise, 41, 709-731. doi: 10.1249/ MSS.0b013e31890eb86
Burd, N. A., Tang, J. E., Moore, D. R., \& Philips, S. M. (2009). Exercise training and protein metabolism: Influences of contraction, protein intake, an sex-based differences. Journal of Applied Physiology, 106, 16921701. doi: 10.1152/japplphysiol.91351.2008

Burke, L. M. (2010). Fueling strategies to optimize performance: Training high or training low? Scandinavian Journal Medicine and Science in Sports, 20(2), 48-58. doi: 10.1111/j.1600-0838.2010.01185.x

Clarys, P., Ramon, K., Hagman, F., Deriemaeker, P., \& Zinzen, E. (2010). Influence of weight reduction on 
physical performance capacity in judokas. Journal of Combat Sports and Martial Arts, 1(2), 71-76.

Czajkowska, A., Lutosławska, G., Mazurek, K., Ambroszkiewicz, J., \& Zmijewskiet, P. (2011). Plasma homocysteine levels, physical activity and macronutrient intake in young healthy men. Pediatric Endocrinology, Diabetes and Metabolism, 17(1), 30-34. PMID:21489354

Daneshvar, P., Hariri, M., Ghiasvand, R., Askari, G., Darvishi, L., Iraj, B., \& Mashhadi, N. S. (2013). Dietary behaviors and nutritional assessment of young male isfahani wrestlers. International Journal of Preventive Medicine, 4(1), S48-S52. PMCID: PMC3665025 PMID: 23717769

Filaire, E., Maso, F., Degoutte, F., Jouanel, P., \& Lac, G. (2001). Food restriction, performance, psychological state and lipid values in judo athletes. International Journal of Sports Medicine, 22 (6), 454-459. doi: $10.1055 / \mathrm{s}-2001-16244$

Finaud, J., Degoutte, F., Scislowski, V., Rouveix, M., Durand, D., \& Filaire, E. (2006). Competition and food restriction effects on oxidative stress in judo. International Journal of Sports Medicine, 27(10), 834841. doi: $10.1055 / \mathrm{s}-2005-872966$

Fleming, S., \& Costarelli, V. (2007). Nutrient intake and body composition in relation to making weight in young male Taekwondo players. Nutrition and Food Science, 37(5), 358-366. doi: 10.1108/00346650710828389

Hawley, J. A., Burke, L. M., Phillips, S. M., \& Spriet, L. L. (2011). Nutritional modulation of traininginduced skeletal muscle adaptations. Journal of Applied Physiology, 110(3), 834-845. doi: 10.1152/ japplphysiol.00949

Kreider, R. B., Wilborn, C. D., Taylor, L., Campbell, B., Almada, A. L., Collins, R., ... Antonio, J. (2010). ISSN exercise and sport nutrition review: research and recommendations. Journal of the International Society of Sports Nutrition, 7, 7. doi: 10.1186/1550-2783-7-7

Maisto produktų ir patiekalų porcijų nuotraukų atlasas. Faktiškos mitybos tyrimo vaizdinè metodinè medžiaga visuomenès sveikatos specialistams, gydytojams dietologams ir dietistams. (2007). Mokomoji knyga visuomenes sveikatos studiju programos studentams ir gydytojams rezidentams. Vilnius: Respublikinis mitybos centras.

Martins, M. I., \& e Rocha, A. (2010). Caracterização antropométrica e consumo alimentar em atletas de remo. Alimentação Humana, 16 (2), 37-46.

Moon, J. R. (2013). Body composition in athletes and sports nutrition: an examination of the bioimpedance analysis technique. European Journal of Clinical Nutrition, 67, S54-S59. doi:10.1038/ejen.2012.165

Moran, D. S., Heled, Y., Arbel, Y., Israeli, E., Finestone, A. S., Evans, \& R. K., Yanovich, R. (2012). Dietary intake and stress fractures among elite male combat recruits. Journal of the International Society of Sports Nutrition, 9(1), 6. doi:10.1186/1550-2783-9-6

Prouteau, S., Benhamou, L., \& Courteix, D. (2006). Relationships between serum leptin and bone markers during stable weight, weight reduction and weight regain in male and female judoists. European Journal of Endocrinology, 154, 389-395. doi: 10.1530/eje.1.02103

Rekomenduojamos paros maistinių medžiagu ir energijos normos. (1999). Valstybès žinios, 102, 2936.

Rossi, L., Goya, R., Matayoshi, M., Pereira, C., \& Bernardo da Silva, J. (2009). Nutritional evaluation of taekwondo athletes. Brazilian Journal of Biochemistry, 3(2), 159-166.

Sillero Quintana, M., Garcia Aparicio, A., Torres García, A., \& Garrido Pastor, G. (2010). Dietary habits and nutritional intervention in elite Spanish athletes. World Congress on Science in Athletics. Barcelona, 2010.

Simatos, J. (2004). Nutritional intake, dietary habits, and physiological profile of 2004 Greek pre-Olympic amateur boxers' team. Hellenic Boxing Federation. Retrieved from http://www.sportsnutrition-inst.org/ PDF/BOXING-personal.pdf.

Skernevičius, J., Raslanas, A., \& Dadelienè, R. (2004). Sporto mokslo tyrimu metodologija. Fizinio išsivystymo tyrimai. Antropometrija (pp. 51-58). Vilnius.

Sučilienè, S., Abaravičius, A. (2002). Maisto produktu sudetis (p. $10-315)$. Vilnius.

Venkatraman, J. T., \& Pendergast, D. R. (2002). Effect of dietary intake on immune function in athletes. Sports Medicine, 32(5), 323-337. 